\title{
Information literacy policies and planning in Ibero-America: Perspectives from an international digital survey
}

Journal of Librarianship and Information Science

(C) The Author(s) 2017
Reprints and permissions:

sagepub.co.uk/journalsPermissions.nav DOI: $10.1177 / 0961000617742449$ journals.sagepub.com/home/lis

@SAGE

\section{Maria Pinto}

University of Granada, Spain

\section{Francisco-Javier Garcia-Marco}

University of Zaragoza, Spain

\section{Gloria Ponjuán}

Universidad de la Habana, Cuba

\section{Dora Sales}

University Jaume I, Spain

\begin{abstract}
An analysis of the state of the policies and plans on information literacy in lbero-America is presented, based on the results of a survey carried out on 42 librarians and academics from 13 different countries, specialized in the development of information skills. The data were gathered from a detailed questionnaire survey conducted during the years 20I2-20I3. The information was collected through open questions, which were later codified and standardized to allow quantitative analysis. In the results and discussion, the information literacy planning landscape in lbero-America is presented in its most general and abstract aspects - the national policies - its visibility in the institutional strategic plans, and its deployment through specific programmes and actions. Widespread progress can be appreciated, as a large number of the institutions to which the invited experts belong have achieved the implementation of systematic programmes (42.9\%), and with the rest, except in one case, involved in preparatory actions, pilot projects and activities of transition from the more traditional users' training activities. Recommendations are offered on the inclusion of information literacy within the national policies for improved digital and media literacy, on its deployment in higher education institutions, and on the need for a truly interdisciplinary effort to articulate the field, looking for an effective and efficient integration of the current and diverse approaches and actions.
\end{abstract}

\section{Keywords}

Digital skills, higher education, Ibero-America, information literacy, information skills, national plans, strategic plans, survey studies, training programmes

\section{Introduction and aims}

This study presents and discusses the results of the third round of an international survey conducted on the situation and perspectives of Information Literacy (INFOLIT) in Ibero-America. The first round was devoted to the conceptual aspects of INFOLIT, mainly its definition, scope and relations with other disciplines and literacies, and was carried on from 20 September 2012 to 20 October 2012.

\footnotetext{
Corresponding author:

Dora Sales, Translation \& Communication, University Jaume I, Avda. Sos Baynat, s/n, I207I, Castellon, I207I, Spain.

Email: dsales@trad.uji.es
} 
The second round dealt with the methodological aspects of INFOLIT, i.e. models and standards, assessment indicators and auxiliary techniques, and was conducted between 20 October 2012 and 25 November 2012. The results of these two previous rounds have been actually published by Ponjuán et al. (2015) in a previous paper.

Finally, in the third round, the panel of experts in INFOLIT from the Ibero-American world were asked to answer a final survey on the information literacy policies, planning, assessment and impact in their countries and institutions. These topics were set down for the third round because of their more specific and specialized nature, to be dealt with after finishing the earlier rounds, which involved defining the concept (first round) and the models, standards and methods to be applied (second round). The third round was carried on from 1 December 2012 to 10 January 2013.

It is important to specify that by Ibero-America we are referring to the cultural space that includes the majority of Latin American countries, together with Portugal and Spain (usually referred as Iberia or Hispania as a culturalgeographical entity), which cooperate within the frame of the Ibero-American Community of Nations for Education, Science and Culture (http://www.oei.es). Information literacy is considered as a key aspect to promote its aims.

More particularly, in this paper we present the results concerning the policies and plans for the development of information competencies in Ibero-America. INFOLIT policies are not only interpreted as those implemented by the State, although States undoubtedly play a key role. INFOLIT policies are rather understood as a framework consisting of vertical, horizontal and still-emerging efforts made by individual or group initiatives with little institutional support to promote the education of the population as regards access to information and its management and dissemination. So INFOLIT policies include those developed by States, institutions, professional bodies and also independent, innovating groups-of-practice. Such projects can be applied either to the population as a whole or to sectors with specific needs. Yet this is not a straightforward task and, as Oppenheim (1994: 136) recognizes, it has its own risks:

whilst in theory IT is a benign technology offering rewards to all in society, in practice the implementation of information technology tools tends to exacerbate the difference between the information rich and the information poor. Governments find it difficult to get to grips with information policy because they have a problem with defining information, which arises from the fact that it is dynamic and innovative, and has social and economic implications - all of which make it hard to handle.

In tune with UNESCO's (UNESCO IFLA, 2005) statements, information literacy is conceived here as a tool to 'empower people in all walks of life to seek, evaluate, use and create information effectively to achieve their personal, social, occupational and educational goals'. This is the general idea about the concept of information literacy within the present paper. Although some custom approaches to the concept and denomination of information literacy are proposed, all of them are influenced by the UNESCO definitions.

Taking into account that there is not much literature on information literacy policies and planning regarding the Ibero-American context, the specific aims of this third stage of the research project, which is presented in this paper, were to sketch out the situation of the policies and plans in the different Ibero-American countries and at the different levels of education; to explore the different underlying theoretical perspectives and their practical implications in greater depth; to determine how INFOLIT policies fit in with wider policies, such as fostering the population's access to technologies and digital information - what is known as digital inclusion - and the multiliteracy movement, adopted by international organizations at the highest level, and more particularly by UNESCO; to identify interaction between the vertical and horizontal dynamics in promoting information literacy; and finally, to systematize the different types of policies, programmes and actions promoted by the different players so as to be able to obtain clear guidelines for effective political action within the field of Information Literacy.

\section{Literature review}

Governmental information policies have been defined by McClure and Jaeger (2008: 257) as 'the set of government directives intended to shape decisions and actions of individuals, organizations, and government agencies'. This definition still reflects the first documented use of the term information policies within the field of government policies, which, during World War I, went by the name of propaganda. Their systematic study from a contemporary perspective dates back to the end of the seventies and early eighties (Instituto Nacional de Prospectiva, 1980; Moore and Steel, 1991; Rowlands, 1997; Rescher, 1998) when it can be considered that all the major lines of current information policies had already been sketched. Despite being very similar across countries in terms of their aims, they nevertheless often have different methodologies. 'Often (as in the UK) the policy is to have no formal policy and to leave it to the marketplace [...] several countries without clearly stated information policies - the UK, the Netherlands, the USA - have strong information industries' (Oppenheim, 1994: 143).

Although the emphasis has traditionally been placed on government policies, in the literature it is acknowledged that information literacy is open to society as a whole, usually outside the scope of government. Within the analytical polarity between state and society, the distinction drawn by Moore $(1997,1998)$ between the two fundamental 
models of information policy is followed by many, these models being: laissez faire (non-interference), in which the State concedes most of the responsibility to the market, and dirigisme, where the State, as a stakeholder, is granted greater responsibility. This is a powerful distinction, but it must be taken in a broad sense, as the responsibility of the non-dirigiste policies lies not only in the market or in the State. Rather, on the one hand, society has many other ways of organizing itself, such as non-governmental organizations, and may include actions performed by individuals or non-institutionalized groups. On the other, the actions performed by the State are not compact, but instead involve people, organizations and structures with different agendas that are strongly linked to sectors of civil society.

Government information policies have evolved throughout history at the same rate as the priority issues and main problems of States, and these are still present today: in times of war and conflicts, they are related to security and the control of public opinion; with the boom of the labour movement and accelerated urbanization, the development of social policies in the field of education and culture, for example, public education and libraries; with the democratic movements and movements of the masses, the promotion of freedom of information and expression, the right to information and the promotion of communication policies; with the development of commerce and industry, attention to competitive intelligence, the development of infrastructures for scientific and technical information or policies on access to scientific production, which also played a key role in the development of information science; with the increasing complexity and growth of the State, the development of statistical information and centres and units of sectorial information and documentation; and with the advent and expansion of the Internet, the development of digital infrastructures, the regulation of telecommunications, digital inclusion or the protection of personal data. Normally these efforts have been made in a relatively independent way by the different government ministries and agencies responsible for their respective areas, with all the unavoidable conflicts that this entails. Yet, together, they make up the wide field of information policies, which extends even further still when the closelyrelated communication policies are added.

Within the Ibero-American context, the policies set by developing countries are especially important (Arnold, 2004). There, UNESCO has played a crucial role in their coordination and definition, as well as in fostering the creation of national information policies. From the nineties, UNESCO has promoted the development of national seminars for the establishment of Information Policies, and disseminated a guide prepared by Montviloff (1990), as the reference text for the development of those policies. Several countries (Mexico, Costa Rica, Uruguay, Cuba) developed national seminars in this sense. These proposals have been characterized by the fact that they link information policies to socio-economic development, that is to say, to an emphasis on information as 'both a commodity and a resource that is collected, protected, shared, manipulated and managed' (Relyea and Hernon, 1968: 176), which must be applied in a relevant way bearing in mind the social and economic factors associated with the access to and availability of information. Several authors have analysed the development and implementation of information policies in Latin American countries (Martínez and Scott, 2001; Ponjuán, 1993; Quindemil, 2008). Interest in this topic peaked in the nineties, but has lost priority today with respect to others, such as information literacy. In Spain, which has a similar trajectory, information policies have received a great deal of attention, some of the most significant studies being those of Cornellá (1997), Caridad and colleagues (Caridad, 1999, 2006, 2011; Morales and Caridad, 2009) and Ros (2010).

On the other hand, specialists in the management of information within organizations have shown a great deal of interest in information policies implemented without any government intervention. This is due to the fact that, at this time, both the Information Resource Management approach and the Information Management approach emerged. These approaches were developed in institutions precisely taking into account institutional information policies, that raise their own strategies coordinated by a Chief Information Officer (CIO) responsible for the information management in the institution. After dating the origin of this topic to the eighties, Orna (2008) claims that it has received less attention from researchers than from professionals, a situation that does not appear to have changed in the last 20 years, although this does not lessen its objective importance (Brown, 1997).

Regarding the aspect of information policies that we are directly concerned with here, that is, information literacy policies, Basili (2011) points out that INFOLIT began as an eminently political concept when Zurkowski (1974) suggested to the US National Commission on Libraries and Information Science that establishing a national programme to achieve universal information literacy by 1984 should be a maximum priority. In that same decade, UNESCO acknowledged that the education of users must be a priority within the national information policies, assigning libraries the role of contributing to the fulfilment of this goal. In the same line, Basili (2009) claims that the library community considered this to be nothing more than a competency to be disseminated among library users, thereby contributing to limit its inclusion within the policy agendas of most European countries. At the beginning of the 21 st century several experts meetings were developed, fostered by UNESCO, IFLA and other organizations, such as the National Forum of Information Literacy from EEUU. These meetings, held in Prague (UNESCO/IFLA, 2003) and Alexandria (UNESCO/IFLA, 2005) produced two Declarations that helped to increase awareness of the 
relevance of these issues in many countries. After these experts meetings, UNESCO organized and funded regional seminars to promote information literacy at a global level. In Ibero-America, in 2009, one of these seminars, for trainers in particular, was developed in Lima (Peru). These actions build greater awareness not only for librarians, but also for faculty and government authorities, on the importance of information literacy.

With respect to Ibero-American countries, the main reference work is that carried out by Uribe and Pinto (Uribe, 2010; Uribe and Pinto, 2014), based on the identification and analysis of 700 cases. Uribe has also developed a map of information literacy in Ibero-America in Google Maps. Likewise, Ponjuán (2010) lists different aspects to be taken into account when drafting a national programme of information literacy, as a strategic approach that can be addressed in the absence of specific policies on the topic. Ceretta and Picco (2013) have attempted to justify the need to establish a model of information literacy within a national plan oriented toward digital inclusion. Also significant is the appreciation of information literacy made by Ponjuánet al. (2015), and the need for its inclusion in educational programmes at various levels, which must be supported by national educational policies.

Finally, and coming down to the operative level of information literacy policies, Weiner et al. (2013) have proposed a panel of actions to be implemented in response to the need for a strategy that makes it possible to 'soften up the system, as the first level of intervention'. The main lines of action proposed call for the development and dissemination of new indicators (Catts and Lau, 2008; Kingdon, 2003; Zahariadis, 1999); holding discussions on the importance of an information literacy policy with representatives from governments and interest groups that can facilitate its inclusion within existing agendas (Kingdon, 2003: 200); and linking information literacy with other policies and problems of public interest. This advice is very useful and we shall see how it is reflected in the research that was conducted, although undeniably, and in the direction indicated by Hernon and Relyea (2003), each country must analyse its conditions, culture, background and other aspects in order to find a suitable strategy that favours the fostering of certain local actions.

In conclusion, we should insist on the need for wellgrounded core strategies that can coordinate and offer support to the multiple initiatives that are being set up, by connecting them with what citizens are calling for and their impact on public advocacy (Crawford and Irving, 2013: 254):

While considerable progress has been made in moving Information Literacy from a 'library centric' model to one which is more society and community based, not enough has been done to integrate Information Literacy policymaking into public advocacy, and indeed Information Literacy policymaking as a distinctive systematic activity scarcely exists.

Thus, the three forces driving information policies in the field of developing information skills could work together in a balanced way, these being: the citizens' needs, programmes and actions generated by stakeholders within the general population, business or government, and the coordinating and integrating efforts made by the public authorities.

\section{Methodology}

The main methodology used in this research project was the survey approach. A structured set of surveys was submitted anonymously to a panel of experts, and the whole process was carried on under the careful watching of a community manager. When necessary, the facilitator refined and specified the questions. The procedure was partially inspired in the Delphi research technique, developed during the Cold War by experts at the RAND Corporation to improve forecasting and policy-making processes, but lacking the intense interaction and consensus drive that Delphi studies require.

The survey general approach was inspiring precisely because the researchers' aim was to contribute to the prospective and strategic planning of the INFOLIT effort in Ibero-America, gathering the knowledge and insights of the panel of experts. As one of the main results of this study has been the parametrization of the research variables, this study allows for future periodic, randomized surveys.

The general characteristics of the panel of experts in the general three-stage survey study were presented in detail in a previous work (Ponjuán et al., 2015), which offers the results of the experts' opinion about the conceptualization and perspectives of information literacy in Ibero-America.

Regarding the participants in the last survey round, specifically devoted to policies and plans, 66 experts were invited. Of them, 52 agreed to participate, and 42 experts from 13 countries, 29 of them women $(69 \%)$ and 13 men (31\%) took part in the third round. Efforts were made to ensure that their distribution according to countries (Table 1) reflected the importance of information literacy activities in each country, but also that a wide range of countries was represented. Thus, 13 of the 20 countries that are usually included in the Pan-Iberian setting agreed to participate, those not taking part being the experts from Bolivia, Honduras, Nicaragua, Paraguay, Puerto Rico and the Dominican Republic, although finally no experts from Venezuela participated in the third round either.

With regard to their profile, the people that were sought should have an academic or professional background within the specific field of Information Literacy, which could be 
Table I. Composition of the panel of experts.

\begin{tabular}{|c|c|c|c|c|c|}
\hline Countries & Invited & Accepted & Participants & Females & Males \\
\hline Argentina & 6 & 6 & 4 & 4 & 0 \\
\hline Brazil & 8 & 4 & 2 & 2 & 0 \\
\hline Chile & 3 & 1 & 2 & 2 & 0 \\
\hline Colombia & 5 & 3 & 3 & I & 2 \\
\hline Costa Rica & I & 1 & I & I & 0 \\
\hline Cuba & 5 & 5 & 5 & 5 & 0 \\
\hline Ecuador & 3 & I & 1 & I & 0 \\
\hline Spain & 9 & 9 & 7 & 2 & 5 \\
\hline Mexico & II & 10 & 9 & 6 & 3 \\
\hline Panama & I & $\mathrm{I}$ & 1 & 0 & I \\
\hline Peru & 5 & 4 & 4 & 4 & 0 \\
\hline Portugal & 3 & 2 & I & 0 & I \\
\hline Uruguay & 5 & 4 & 2 & I & I \\
\hline Venezuela & 1 & I & 0 & 0 & 0 \\
\hline Total & 66 & 52 & 42 & 29 & 13 \\
\hline
\end{tabular}

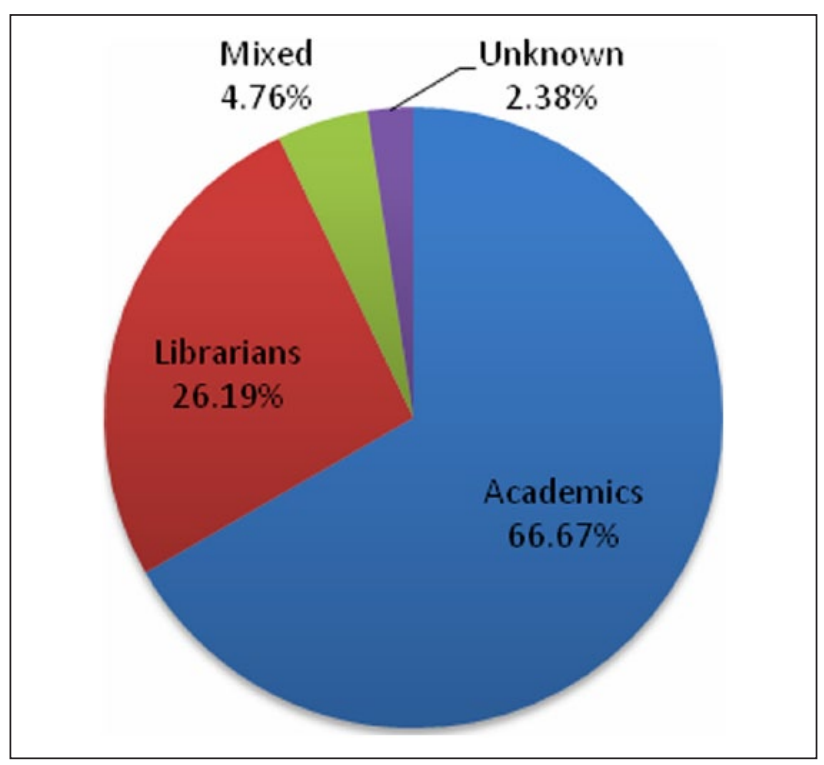

Figure I. Professional profile of the experts.

objectively proven in their $\mathrm{CV}$ by the accreditation of publications, positions and projects. Of the total number, $67 \%$ are academics (28), many of whom also have professional experience, and $31 \%$ are practising librarians (13), of whom $5 \%$ have been or are also academics (2). See Figure 1.

As regards their level of academic qualification, $48 \%$ have a Doctor's degree (20), 24\% have a Master's degree (10) and 26\%, a Bachelor's degree (11). See Figure 2.

In terms of their degree speciality, $61.9 \%$ studied Librarianship and Information Sciences (26), 9.5\% studied Communication (4), 9.5\% Philosophy and Arts (4), 4.8\% Psychology (2) and 2.4\%, respectively, Education (1), Geography and History (1), Information Technology (1), and Translation and Interpreting (1). See Figure 3.

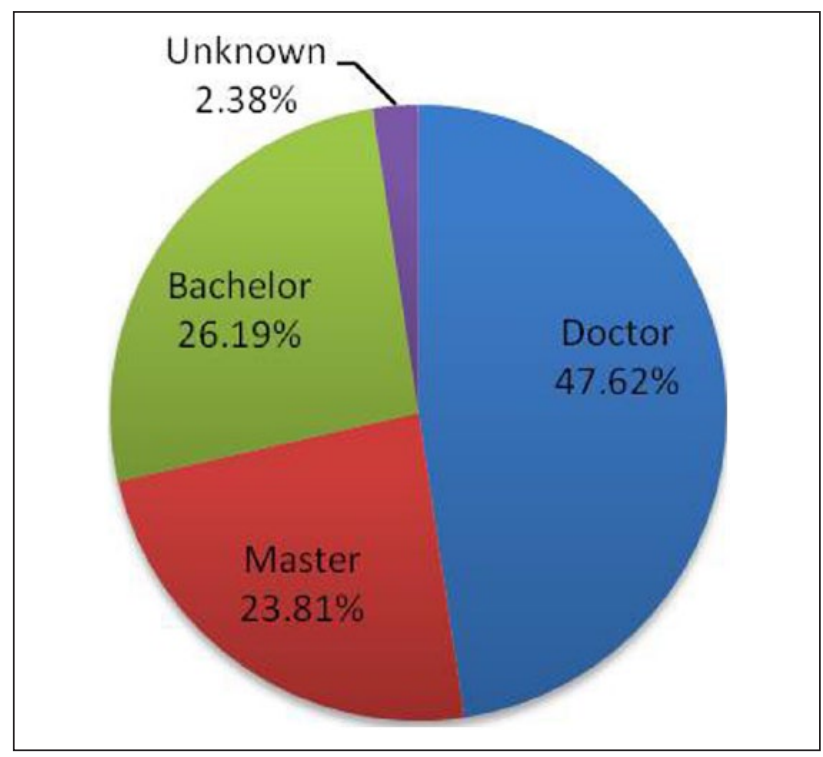

Figure 2. Level of studies.

All the experts belong to the area of higher education, but nearly half of them have some background in another type of area of intervention (see Figure 4). Thus, 52.4\% focus their work on the area of information literacy in higher education (22), $21.4 \%$ take a comprehensive perspective of the different levels (9), 9.5\% are specialized in information literacy in schools (4), 7.1\% in teacher training (3), and $2.4 \%$, respectively, in researchers (1), public libraries (1) or consultancy for professionals (1). Thanks to the wide range of experience and the variety of approaches of the experts, we believe it has been possible to reach a general perspective of the information literacy policies in Ibero-America.

The questions that were asked in this part of the study, which can be seen in the Appendix, were open-ended questions, preceded by a text inviting thought and contextualization. In some cases they were followed by another text asking for specific information. The data obtained through the online survey are available at: http://infocompetencias.com/cartografia3

In this round on the set of surveys, the experts provided answers that were more local in their scope and perspective than those offered on the conceptualization and dimensions surveys (Ponjuán et al., 2015). This is partly a result of an increased focus of our research on the real implementation of policies through strategic planning, programme development and pilot projects; and also a consequence of the stress that the experts put on their real experience.

As could be expected, the use of open-ended questions represented an important challenge when it came to coding the data, but it was considered to be a suitable strategy in a pioneering study like this one, since it allows the collection of rich and varied information that reflects the complexity 


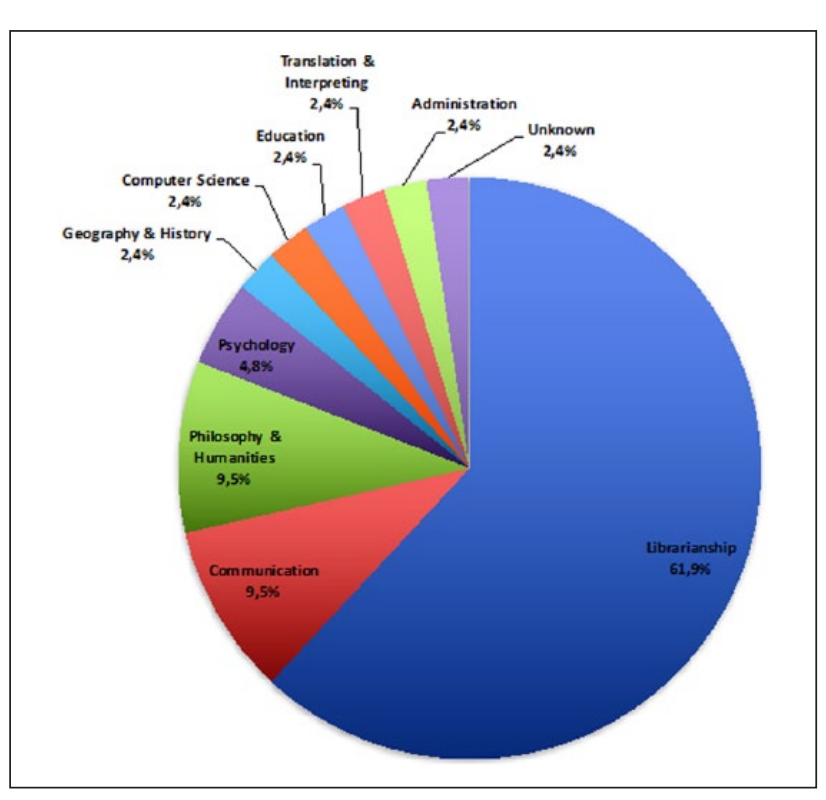

Figure 3. Degree speciality.

of the map of information literacy in Ibero-America. The analysis and classification of information provided by the experts will make it possible in the future to construct more specific, closed and easily applicable instruments that will facilitate the monitoring of policies, strategies and actions involving information literacy in Ibero-America as well as other parts of the world. In the results and discussion section, the reader can also follow the processes of content analysis and normalization that were carried out in order to transform qualitative data into quantitative data, the information being synthesized with the greatest possible amount of objectivity. Finally, the normalization that was carried out based on the answers to the survey's questions has also allowed us to build a normalized instrument for monitoring the evolution of information literacy policies and plans that can be applied in other areas of the world.

\section{Results and discussion}

The results and discussion have been grouped in four subsections, which refer specifically to national policies, institutional policies, strategic plans of institutions and, lastly, existing programmes and actions or those due to be implemented in the short term. Thus, the panorama of information literacy planning in Ibero-America is presented from its most general abstract aspects (national policies), through its visibility within the policies and strategic plans of institutions, to its specification in definite programmes and actions.

\section{National policies}

Experts were asked to 'Summarize which is the vision about INFOLIT in your country, and in your institution in particular' in an open question, regarding UNESCO's

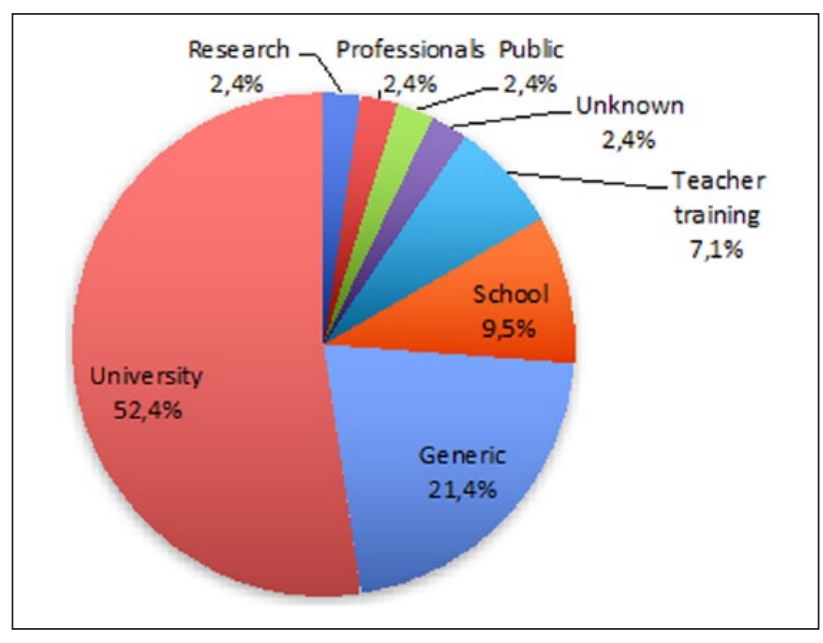

Figure 4. Specialization within the field of Information Literacy.

request to governments that they formally recognize INFOLIT as a key generic competence in all the educational and vocational training levels. Some reference to appropriate formal documents declaring the contextual aspects and the policies regarding INFOLIT was given as a result of this general question.

When it comes to understanding the level of development of national policies, there are several factors that are decisive. In general, one of them is the level of economic and social development and the extent to which activities requiring an important use of information and communication networks have been incorporated within globalization. But it is also important to distinguish the level of education, as the levels of compulsory education are notably more regulated than those of higher education. Therefore, in the early stages of education the existence or absence of plans is apparent at the national level, whereas in higher education the initiative lies more within the field of the institutions, which generally enjoy a high degree of autonomy. Hence, in higher education, the national policies are usually established by means of agreements, through coordination instruments.

Information literacy policies are not addressed at the national level in most countries. Only 7 of the 42 experts $(16.7 \%)$ reported the existence of plans in their countries. These were Colombia ( 1 out of 3), Cuba ( 1 out of 5), Mexico ( 2 out of 9) and Peru (3 out of 4 ), although consensus among the national experts only existed in this last country. These divergent results seem to be due both to the dynamics of coreto-periphery diffusion and, above all, to different interpretations regarding what the existence of a national plan actually involves. This may range from the existence of a plan drawn up by a representative institution at the national level to, in its strictest degree, the existence of a ministerial plan.

Another important issue is to know whether the information literacy policies reach all the different levels of 
education or only universities, something that occurs in the best of cases in most countries. Hence, for example, in the case of Mexico, although the experts report on the range of initiatives that are underway, particularly in higher education, several experts also noted the absence of an integral plan for the different levels of education as a whole.

Indeed, in Peru information literacy is considered a strategy within Goal 2 of the Peruvian Digital Agenda 2.0, promoted by the Comisión para el Seguimiento $y$ Evaluación del Plan de Desarrollo de la Sociedad de la Información (CODESI - Commission for the Monitoring and Assessment of the Information Society Development Plan), which seeks to 'Integrate, expand and ensure the development of competencies for the population's access to and participation in the information and knowledge society' (Academic expert, Peru). Nevertheless, efforts are still focused 'on enhancing connectivity and the use of technologies to overcome the digital gap, and therefore the development of information competencies does not yet occupy a core role' (Academic expert, Peru).

In many other countries, the experts refer to the existence of national digital inclusion plans, such as the Plan Conectar Igualdad (Equality Connect Plan) in Argentina, which is dedicated to providing each child and teacher in secondary schools with a computer; the Ceibal Plan in Uruguay; the Politica Nacional de Información (National Information Policy) in Cuba; or the Secretary of Public Education's (SEP) Enciclomedia Plan in Mexico. In Colombia, INFOLIT is under development, originally linking to reading and writing literacies and digital literacy. As an academic expert (Colombia) puts forward:

in the broad sense of being competent in information management, INFOLIT is not part of the policies or the priorities of education and cultural institutions. The experiences that have been developed are due to the particular interest of some institutions and especially the people who manage library systems. In this sense, the topic is still a library concern more than an area of general interest.

Another Colombian academic expert reaffirms this view:

As a national education policy there is still no acknowledgement for INFOLIT. The focus is placed mainly on digital-computing literacies. Regarding universities, including the University of Antioquia, the acknowledgement has been introduced not as a policy for all academic programmes but for some particular programmes that have been motivated thanks to the collaborative work of lecturers and librarians. That is, it goes bottom-up. Nonetheless, in the Colombian university system there are some cases of INFOLIT subjects that have been endorsed for all programmes as part of an institution policy, as in University of Rosario and University of Santo Tomás de Bucaramanga.

In this respect, several experts stress the importance of taking advantage of digital endowment and training programmes to include teacher training in information literacy. Thus, in Uruguay they are working precisely in that direction with the Universidad de la República's Programa de Desarrollo Académico de la Información y la Comunicación (PRODIC-Information and Communication Academic Development Program), which as an academic expert from Uruguay states: 'it looks to overcome this shortage through the development of models for INFOLIT training'.

As far as national programmes are concerned, one aspect that should be underlined as an important success factor is the importance of the coordination of information literacy at the national and international levels by the institutions involved. Although higher education institutions enjoy a growing degree of autonomy, coordination carried out either directly or through professional associations is a very efficient mechanism for disseminating successful projects and best practices. In the same line, another case worth highlighting is the effort made by the Brazilian general council and the regional councils of the Federação Brasileira das Associações de Bibliotecários (FEBAB Brazilian Federation of Librarians' Associations), the Instituto Brasileiro de Informação em Ciência e Tecnologia (IBICT - Brazilian Institute of Information in Science and Technology) and by reference institutions like the Universidade de Brasilia. But in spite of all these efforts, a Brazilian academic expert states that: 'we don't have a defined policy for the Brazilian context regarding information competencies, and we just have been able to introduce some subjects in Information Studies postgraduate programmes' Likewise, in Peru, the Consorcio de Universidades del Perú (Peruvian Universities Consortium) is actively involved in the coordination and development of teacher training activities. In Spain, the Grupo de Trabajo en Alfabetización Informacional (Information Literacy Workgroup) of the Red Española de Bibliotecas Españolas (REBIUN - Spanish Network of Spanish Libraries) has been working on coordination for several years, with a high degree of success. In Portugal, an academic librarian expert thinks that the view on INFOLIT policy:

is fragmentary. Each institution adapts the model or the methods that are believed to be the best (the most used is SCONUL). At ISPA-IU we apply a mixture of several standards and models, and also the norms for Higher Education (for instance: SCONUL, Big 6, mixed with Johnson and Webber perspective).

In Mexico, the Consejo Nacional de Asuntos Bibliotecarios de Instituciones de Educación Superior (National Council for Library Affairs in Institutions of Higher Education) has also adopted the norms on information literacy.

\section{Institutional policies}

Many institutions are taking the first steps toward developing information literacy policies and, although they have 
still not been implemented, advances are also being made in the processes of raising the awareness of those responsible. In general, there are observable policies for training in the digital technologies and many experts from the different countries point to these programmes as a clear opportunity to position the information literacy agendas.

Hence, at least 20 of the 42 experts (47.6\%) consider that their institution has a well-defined institutional policy. These experts were from 8 of the 14 countries: Colombia (1 out of 3), Cuba (1 out of 5), Ecuador (1 out of 1), Spain (3 out of 7), Mexico (8 out of 9), Panama (1 out of 1), Peru (3 out of 4) and Portugal (1 out of 1). In Argentina, moreover, one of the experts stated that it is being considered as an action in the strategic plan, but has still not been developed.

Mention should be made of the consensus among the experts from Mexico, with the notable efforts made by the Dirección General de Bibliotecas of the Universidad Nacional Autónoma de México (UNAM), which has had a Programa de Desarrollo de Habilidades Informativas (Information Skills Development Program) since 2000, as part of the Programa de Desarrollo de Competencias para Toda la Vida (Program for the Development of Lifelong Competencies). Given the UNAM's involvement in baccalaureate programmes, it has also offered training in information competencies to teachers at that level and has developed self-training materials for students. The Colegio de México, the Universidad Veracruzana or the Universidad Autónoma de Ciudad Juárez, among others, have also been developing systematic programmes for some years. As a Mexican academic expert states:

for over 15 years there has been an explicit acknowledgement of the relevance of INFOLIT programmes, though we have not been able to consolidate it within the curricula. This support has become more natural as our university is also planning to introduce an education model based on competencies.

In particular, the Colegio de México offers its own interesting model, grounded in the academic as well as professional profile of its teachers-librarians, with a long tradition in the development of information competencies incorporated within the curriculum that dates back to the early days of the Institution.

In Cuba, interesting initiatives include the Sistema Nacional de Información en Ciencias de la Salud (National Health Sciences Information System), a policy for the development of INFOLIT for all the libraries in the National Health System, created by the Centro Nacional de Información de Ciencias Médicas (CNICM - National Medical Science Information Center. Likewise, at the Universidad Central Marta Abreu de las Villas (UCLV) some faculties and libraries 'have an INFOLIT programme since 2006 as the result of a Master's thesis, with particular actions for their implementation at diverse levels within the University', as a Cuban academic expert puts forward.

In Spain, the situation is unbalanced, within a generalized awareness of the importance of developing information competencies. At one end of the continuum there are the universities that include compulsory subjects for their students, as is the case of the Universitat Oberta de Catalunya (Catalonia Open University) or the Universidad Carlos III in Madrid, while at the other we find those where training is only offered by the library to users who ask for it. Intermediate cases could include the official recognition of credits within a percentage of those from optional subjects, the model followed by the Universidad de Zaragoza, or including the subjects of information science or introduction to research, which contain a large part of the contents of information literacy, within the academic programme.

\section{The presence of INFOLIT in the strategic plans of institutions}

The fact that a field of activity is explicitly included within the strategic plan of an institution is generally recognized as a key indicator of the objective relevance that is granted to it. Indeed, the presence of information literacy in the strategic plans of teaching institutions is clear proof that it is considered as being at the highest and firmest level of its priorities by the institution's uppermost governing bodies.

In this respect, 21 of the 42 experts (50\%) point out that information literacy is included in the strategic plans of their institutions, namely, in Argentina (1 out of 4), Colombia (2 out of 3), Cuba (2 out of 5), Ecuador (1 out of 1), Spain (4 out of 7), Mexico (8 out of 9), Peru (2 out of 4) and Portugal (1 out of 1). Let us now analyse these results in a little more depth.

In Argentina, only one of the four institutions to which the Argentinean respondents belong addressed INFOLIT within the objectives of the library, i.e. the Universidad de Córdoba. Following an Argentinian library expert, more specifically two actions have been included among the operative objectives of the strategic goal 'Offer support to users in their teaching, learning and research activities', namely:

- Implement information literacy programmes oriented toward the development of at least four of the seven competencies fostered by INFOLIT.

- Promote information literacy in the university curricula through participation in courses, seminars and other teaching activities related to research methodology courses, thereby offering training in bibliographical and documentary research.

In Colombia, information competencies are considered to be implicit within research competency at the Pontificia 
Universidad Javierana, and are included as such in the strategic plan of the library at the Universidad de Antioquía. As an academic expert from that University states, INFOLIT

is included in the plan for the Library, and the ultimate goal is to have a permanent course in each faculty. For the moment this has been introduced in fifteen faculties. In the case of the Escuela Interamericana de Bibliotecología the future librarians are trained on this topic thanks to two subjects, one on the theoretical basis and the other one focused on practice.

In Cuba, the Information Literacy Program and the development of information competencies within the National Health System are present in the CNICM's strategic planning, where the aims, criteria for measurement and action plan are stated. At the Universidad de las Ciencias Informáticas (UCI), it is also contemplated within its library's strategic plan.

In Ecuador, information literacy is considered an essential development aim within the strategic plan of the Escuela Politécnica del Ejército.

In Spain, the Universidad de Zaragoza expressly mentions information literacy in point 4.2.4. of its strategic plan 'Integration of the training activities of the library within the educational plans of the Universidad de Zaragoza', in which Goal 4 is stated in the following terms: 'To facilitate the user's autonomy by fostering free access to the collections and the development of both virtual and in-person self-service mechanisms and systems'. The 2010-2013 strategic plan of the library of the Universidad Complutense de Madrid also stated, in point 2 of subsection 4:

Designing training actions that promote the acquisition of information competencies.

Designing a training system for acquiring information competencies that allows them to be incorporated into the academic programmes of the University, thereby enhancing virtual training.

Producing homogeneous training programmes at the Complutense library, standardizing the methodology, contents and formats of the different types of courses (zero, graduate, postgraduate, PDI - teaching and research staff, TFM - Master's degree final project, $\mathrm{TFC}$ - Bachelor's degree final project).

It is also present in the plans of the Universidad de Granada and the Universitat Oberta de Catalunya. But as an expert librarian from that university explains, though INFOLIT

is part of the strategic plan of my institution, and that is very important ... [however] it would be much more important that it could be included in the curricula, not as a repetitive formula but as an evidence of the conviction and knowledge from the side of the people who write the curricula, regarding the relevance of INFOLIT as a global result of each degree.

In Mexico, the UNAM considers it a priority to develop information competencies, as a strategy for furthering incorporation into the knowledge society. It is also taken into account at the Colegio de México, the Universidad Veracruzana and the Universidad Autónoma de Ciudad Juárez, in this last case at both the university and library levels.

In Peru, information literacy is part of the Strategic Plan of the Library System of the Pontificia Universidad Católica del Perú (PUCP), the first aim of which specifically seeks to ensure that $70 \%$ of those entering undergraduate, postgraduate and doctoral studies in the period 2016 are trained in the Information Literacy Program (INFOLIT).

Finally, in Portugal, information literacy is included within the strategic plan of the Higher Institute of Applied Psychology (ISPA). As a Portuguese academic expert puts forward: 'It is part of the Library strategic plan and of the subjects that I teach at graduate and postgraduate levels'.

Several experts note that information literacy can be considered implicit in the mentions that are made in the strategic plans of institutes through the development of research competencies. Although strictly speaking INFOLIT cannot be considered as contemplated within the strategic plans, it is true that these experts reflect the possibilities offered by the mission of training researchers and training in research as a means to place the development of information competencies within institutional strategic plans.

It should be noted, however, that many experts are optimistic as regards the consideration that the institution has toward information literacy. This can be seen in the fact that they interpret general statements about the training of well-informed citizens or more specific references aimed at the field of digital matters and the information and communication technologies as explicit support. In some cases, the opposite occurs: some experts consider the approach to training as very narrow - limited to searching and accessing - and think that the programmes therefore cannot truly and fully take information literacy into consideration.

\section{Characteristics of the training actions}

Information literacy actions vary greatly in terms of their level of institutional backing and formalization, academic recognition (in official study time), their extension on the educational map of the institution, i.e. areas, degrees and subjects involved, academic level (initial degree, advanced degree, postgraduate, doctoral, teacher training), and the duration in working hours of the students or their agent, i.e. librarians or teachers. 


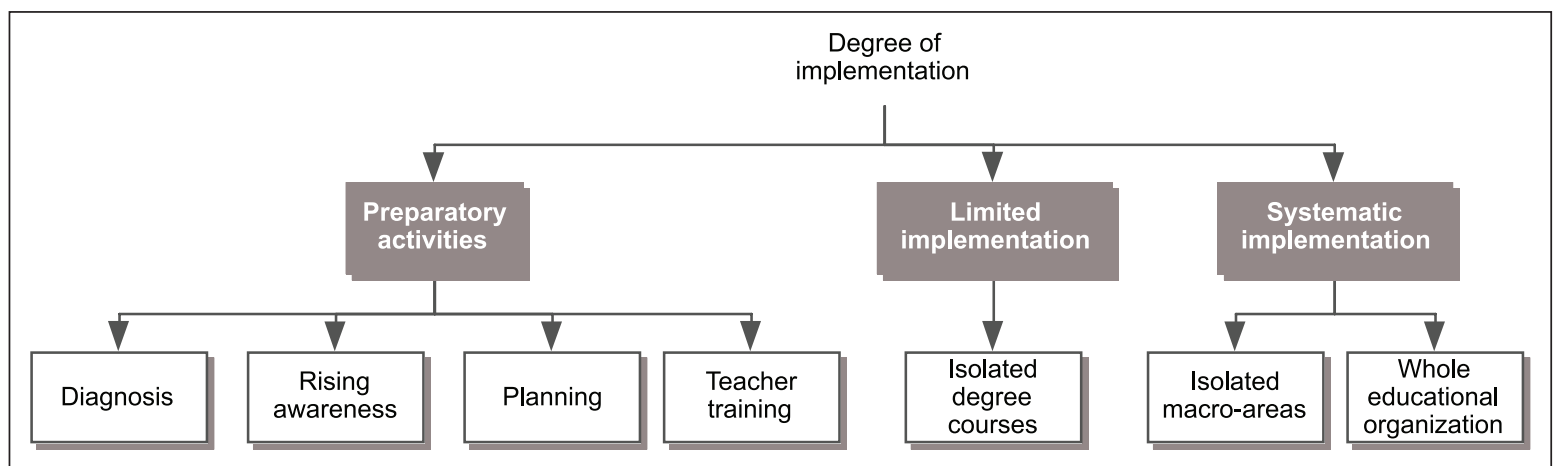

Figure 5. Classification of information literacy actions.

Table 2. Number of institutions by country in which each level of implementation has been evidenced.

\begin{tabular}{|c|c|c|c|c|c|c|c|c|c|c|c|c|c|c|}
\hline \multirow{2}{*}{$\begin{array}{l}\text { Action of } \\
\text { implementation }\end{array}$} & \multicolumn{14}{|c|}{ Number of institutions with evidenced actions } \\
\hline & Argentina & Brazil & Chile & Colombia & $\begin{array}{l}\text { Costa } \\
\text { Rica }\end{array}$ & Cuba & Ecuador & Spain & Mexico & Panama & Peru & Portugal & Uruguay & Total \\
\hline None & & & & & & & & & & & I & & & 1 \\
\hline Awareness-raising & & 1 & & & & & & & & & & & & 1 \\
\hline Diagnosis & & & & & & & I & & & & & & I & 2 \\
\hline Planning & I & & & & I & & & & & & & & & 2 \\
\hline Teacher training & & & & & & & & & & I & & & & 1 \\
\hline $\begin{array}{l}\text { Isolated actions by } \\
\text { the library }\end{array}$ & 2 & & 1 & & & 1 & & 1 & 1 & & & & 1 & 7 \\
\hline Isolated seminars & I & & & & & & & & & & & & & 1 \\
\hline $\begin{array}{l}\text { Individual degree } \\
\text { courses }\end{array}$ & & & 1 & 1 & & 2 & & 2 & & & 2 & & & 8 \\
\hline Systematic program & & 1 & & 2 & & 2 & & 4 & 8 & & I & I & & 19 \\
\hline Total & 4 & 2 & 2 & 3 & 1 & 5 & I & 7 & 9 & I & 4 & I & 2 & 42 \\
\hline $\begin{array}{l}\text { Percentage of } \\
\text { institutions with a } \\
\text { systematic program }\end{array}$ & 0 & 50 & 0 & 67 & 0 & 40 & 0 & 57 & 89 & 0 & 25 & 100 & 0 & \\
\hline
\end{tabular}

We have thus attempted to organize the actions analysed across a continuum that ranges from the preparatory activities (raising awareness, diagnosis, planning, teacher training, etc.), through limited or pilot projects (actions carried out by the library, teaching seminars, subjects in some degree courses) to systematic programmes designed for 'macro-areas' or, in the best of cases, for the whole educational organization (Figure 5). This continuum emerged during the analysis phase, as a moderate way of organizing an otherwise very diverse set of data, and it is congruent with a simplified and limited version of the policy cycle (e.g. Jann and Wegrich, 2007), which therefore suggests a fertile framework for subsequent studies.

The different experts situate their institutions as shown in Table 2.

According to these data, 1 does not report any action $2.4 \%, 6$ institutions are in the preparatory phase $-14.3 \%$, 9 are in the isolated projects phase $-21.4 \%, 8$ are in individual degree courses $-19 \%$, and 19 are implementing a systematic program $-45.2 \%$. These percentages indicate that there is a good degree of development in almost half the educational institutions and an interest in developing solid programmes in the vast majority of the others.

The number of institutions with a systematic programme over the total number for each country could provide a rough approximation of the situation by country. Thus, Portugal, Mexico and Colombia present a high degree of implementation; Brazil, Cuba and Spain display a medium level; Peru is under way; and the other countries are in the stage of preparation or transition from a model of training library users. But this general glimpse must be taken as hypothetical because the study was not designed to provide a representative sample. The sample refers to experts rather than institutions and it is insufficient for some countries.

In the following, further information is provided about the different levels of development of information literacy in the experts' reference institutions. 
The first level consists of awareness-raising, which is a frequent state in the educational institutions that are preparing their projects, and which in some way remains permanently, even in institutions that have already implemented a plan through marketing activities, with the aim of maintaining the users' attention and willingness. In this study, no institution that has still not undertaken other preparatory processes has been detected.

The second level is to carry out diagnostic and planning studies. One good example of this stage is the initiative implemented by the Escuela Politécnica del Ejército del Ecuador, which has set up a CMI (from the Spanish for Information Management Competency) Observatory in collaboration with other Ecuadorian universities.

The implementation phase can be considered the third level. This level usually begins with teacher training activities and goes on through new activities developed by the library or in collaboration with already-existing subjects, especially those involving initiation in scientific research. These actions cover a wide range of activities, but a progressive course can be seen. Programmes usually start with training in the use of library collections and services. General or specialized sources of information are then addressed, depending on the users' level, and resource assessment. The third step involves teaching how to use library management applications and the fundamentals of bibliographical citation. Finally, more extensive levels and projects address issues referring to publishing, such as selection of the most suitable publishers and journals for publication, together with the norms and strategies for writing scientific papers. Another frequent practice is to include information and references about the above- mentioned topics on the libraries' websites and in their newsletters.

With respect to the level of studies catered for and the granularity of the courses, 23 of the 42 experts provide clear data. According to these experts, 19 institutions have programmes catering for students entering graduate studies $(82.6 \%), 9$ of which only address this level $(39.1 \%)$; only 9 (39.1\%) offer a more advanced (intermediate) course in the degree; $9(39.1 \%)$ offer courses for postgraduates; and $6(26.1 \%)$ do so for doctoral studies. Moreover, 11 of the 42 institutions (26.2\%) have a programme for officially recognizing credits taken in INFOLIT programmes. Of these latter, 8 of the $42(19.0 \%)$ include training credits as compulsory subjects for all undergraduate students: one each in Colombia and Cuba, two in Spain and four in Mexico.

Hence, there are several universities that have implemented Information Literacy as a compulsory course for all their degrees, as is the case of the Universidad del Rosario and the Universidad Santo Tomás de Bucaramanga in Colombia (Uribe, 2010), and the Pontificia Universidad Javierana, also in Colombia. In Cuba, training in INFOLIT is provided at the Universidad de las Ciencias Informáticas
(UCI - Computer Sciences University) through the subject Professional Practice. In Spain this is done in the same way at the Universitat Oberta de Catalunya, in the subject 'Use of the ICTs', and at the Universidad Carlos III in Madrid, in the subject entitled 'Techniques for Searching for and Using Information'. In Mexico, similar courses have been implemented in several faculties of the UNAM, the Colegio de México, the Universidad Veracruzana and the Universidad Autónoma de Ciudad Juárez.

Training in information competencies is therefore generalized for the training of students entering university, drops somewhat at the intermediate level, although it is carried out, and is addressed to a lesser extent at the doctoral level, although a quarter of the centres that specify their level do have it. Around a quarter of them have programmes for officially recognizing credits for students that study the courses, and practically a fifth of the institutions have a compulsory training programme, which points to a very strong, although not necessary, link between including it in the curriculum as a compulsory subject or material and the official recognition of credits.

The official recognition of credits is an important incentive for students at institutions or levels of education in which the courses are not compulsory. There are, however, other possible motivational mechanisms, such as making users' participation in a training workshop a requirement to be able to renew or extend their library users' card, something that is done in some libraries at the UNAM.

Another interesting aspect is that some of the experts pointed out the existence of barriers hindering attempts to implement official programmes in their institutions. Several of them complain that the systematic programme carried out by the library is not adopted by the institution as a whole or given support by teaching staff. Some of these observations may explain why at other moments in history the decision has been made to include specific subjects dealing with documentary information or at least some compulsory material within the subjects of scientific methodology and introduction to research within the curriculum of different degree courses as perhaps the only necessary and sufficient way to integrate the skills within the curriculum. Furthermore, as a Spanish academic expert states, there are other underlying reasons that obstruct the full implementation of training actions:

I think that there is a lack of communication between the parts that could promote INFOLIT (library and academic area), but regretfully I also think that the current situation of the new degrees (much restricted due to diverse reasons) doesn't help at all. Even more, the delicate economic situation causes that, at a strategic level, neither the faculties nor the higher institutions at the University consider the implementation of new actions in any context.

As regards the agents responsible for training, 19 out of the 41 experts who reported the existence of a programme 
in their institutions stated that the programmes at their institutions were directed by the libraries $(46.3 \%)$, four said it was done by teaching staff $(9.7 \%)$, six reported that it was carried out by both sectors $(14.6 \%)$ and three indicated that it was performed in truly coordinated actions $(7.3 \%)$. Therefore, the actions directed by libraries, with the support of teachers from the area of Librarianship and Information Science in those cases in which they exist, stand out above the rest. Yet, there are interesting cases led by members of teaching staff, as happens at the Pontificia Universidad Javierana (Colombia), where information literacy is linked to research training, and more particularly to what are known as 'Research projects'.

Finally, the experts also provide information about teacher training projects and programmes in nine cases. Teacher training generally takes place within the professional development plans for library staff (3) or within the framework of the different levels of librarianship and information science studies, in the form of on-demand seminars (1), specifically dedicated subjects (4) or in a dispersed way, spread over several subjects (1), which makes it more difficult for them to be recognized as such and prevents any clear research from being conducted on the teaching aspects of INFOLIT within the current work setting.

\section{Conclusions and recommendations}

The present study has been fruitful in practical recommendations for the development of IL programmes that have been summarized in Table 3 and will be addressed subsequently.

Although the state of development of information literacy varies widely in the different countries and institutions, the fact is that a large number of institutions to which the invited experts belong have implemented systematic programmes $(42.9 \%)$ while the rest, except for one case, are involved in preparatory actions, pilot projects and activities fostering the transition from traditional user training.

There is still a great deal of overlap between the traditional concept of user training and the integrated development of information competencies. As a result, a certain amount of the apparent incoherence in the appraisal of the degree of development of the institutional policies and strategies regarding information literacy is due to the different perspectives of the experts. Thus, one group deems that activities to promote and foster access to the library and its resources are sufficient while others, especially academics and researchers, would like the concept to have a wider scope.

There is also a large amount of confusion concerning the concepts of digital and information literacy, with governments and institutions paying more attention to the former, although the possibilities of achieving a synergy between them are high. INFOLIT is also likely to become more visible owing to the concern for digital literacy, since many are aware that it also involves skills that are not solely related with access to networks and computing and the use of information and communications technologies tools. This would require that visual and digital literacies are specifically addressed in INFOLIT national and institutional plans, according to the most recent proposal of international bodies (UNESCO/IFLA, 2005):

Information Literacy lies at the core of lifelong learning. It empowers people in all walks of life to seek, evaluate, use and create information effectively to achieve their personal, social, occupational and educational goals. It is a basic human right in a digital world and promotes social inclusion of all nations.

As a consequence Karpati (2011:1) states:

digital literacy has become much more than the ability to handle computers - just like traditional literacy and numeracy, it comprises a set of basic skills which include the use and production of digital media, information processing and retrieval, participation in social networks for creation and sharing of knowledge, and a wide range of professional computing skills.

On the other hand, an optimistic acceptance of the implications of the emphasis placed on the digital shift in education by governments and the authorities may lead to an overestimation of the potential of accepting information literacy as such. In this regard, the emphasis on generic competencies and on multiliteracies is at the same time an opportunity - in the sense that it offers a framework in which to firmly place information literacy and the contribution made by the information professions - and a threat, since it may blur and subsume the progress already made in many institutions as part of the transdisciplinary efforts being made by many different professionals. Finding a secure framework for cooperation among the different interdisciplinary agents involved is therefore a decisive challenge.

Another important movement that is proving to be essential to position information literacy is the growing emphasis on generic competencies within the lifelong learning framework. Within this framework there is clear consensus acknowledging access to knowledge, together with its management and public dissemination, as a fundamental generic competency.

At the school level, we recommend taking advantage of the increased efforts that are being made to incorporate information and communication technologies, since nearly all countries have national plans aimed at reducing the digital gap. In general, training in information and communications technologies at different levels, i.e. school, university and teacher training, is a great opportunity lay 
Table 3. Main recommendations derived from the answers to the survey.

\begin{tabular}{|c|c|}
\hline Areas & Recommendations \\
\hline Definition & Conciliate the generic approach proposed by academics and the specific fostered by librarians \\
\hline \multirow[t]{5}{*}{$\begin{array}{l}\text { Cooperation and } \\
\text { alliances }\end{array}$} & $\begin{array}{l}\text { Insert INFOLIT into the digital literacy efforts favoured by governments and institutions, but without losing } \\
\text { specificity and personality }\end{array}$ \\
\hline & $\begin{array}{l}\text { Find a framework for cooperation among the different interdisciplinary agents that cooperate in the generic } \\
\text { competences and multiliteracies movements }\end{array}$ \\
\hline & Promote alliances with the long-life learning agenda \\
\hline & Lobby policy-makers, especially in the most highly regulated areas, e. g. school and specialized education \\
\hline & $\begin{array}{l}\text { Specialize agents in the task they can better deliver according to their backgrounds and experience, but } \\
\text { working in a team }\end{array}$ \\
\hline School level & $\begin{array}{l}\text { Insert INFOLIT into the programmes that promote the adoption of information and communication } \\
\text { technologies at schools, stressing the importance of contents and information strategies beside information } \\
\text { and communications technologies }\end{array}$ \\
\hline \multirow[t]{4}{*}{ University level } & Promote INFOLIT in the frame of inter-library cooperation and higher education library networks \\
\hline & Recognize, supporting and disseminating innovative and successful INFOLIT projects \\
\hline & $\begin{array}{l}\text { Connect INFOLIT programmes with research-oriented subjects, especially those in relation to research } \\
\text { methodology, initiation to research work and end-of-grade, end-of-Master's and Doctoral assignments }\end{array}$ \\
\hline & Incorporate INFOLIT as requirement worth a certain number of credits in undergraduate training \\
\hline \multirow[t]{6}{*}{ General procedure } & I. Lobby and awareness-rising, backed with ongoing marketing activities \\
\hline & 2. Do the diagnosis and planning \\
\hline & 3. Train the trainers and recognize and integrate pioneers \\
\hline & 4. Re-engineer existing subjects and users' training courses. Design from scratch those that are not available. \\
\hline & 5. Promote the official recognition of INFOLIT activities in academic credits \\
\hline & $\begin{array}{l}\text { 6. Promote the official integration of specific INFOLIT courses into existing educational programmes, } \\
\text { whenever well-grounded by the set of competences required in their educational profile }\end{array}$ \\
\hline
\end{tabular}

emphasis upon the training related to the information strategies and contents, beyond the indispensable learning about technologies.

At university level, particularly swift progress is being made in countries where there is a coordinated library system, capable of proposing and promoting policies among institutions as a whole. Success stories include the information literacy activities for new first-year students and also the collaboration with subjects related to research methodology in different degree courses and cross-curricular activities such as final year projects. The different research-related subjects and activities are an ideal field of work for setting up alliances and collaborative activities between libraries and teachers aimed at developing information skills. In this sense, entry to undergraduate and doctoral degree programmes has been identified as the best moment to offer students support to develop their information skills. More particularly, many experts consider information literacy should be incorporated as an assessable requirement worth a certain number of credits in undergraduate training, within the programmes involving initiation in research.

The strategies followed to promote information literacy in compulsory, higher and specialized education, as well as lifelong learning, should necessarily be different. In compulsory education, the policies are highly centralized and the frameworks strongly regulated, and therefore the promotion of INFOLIT must involve convincing the political authorities through persuasive actions carried out by organizations at the appropriate level. The higher education market is, however, becoming increasingly less regulated and, as a result, in most countries the institutions enjoy greater autonomy. Hence, in order to advance it is necessary to recognize pioneering initiatives and seek coordination bearing in mind that the larger the university system is, the more this is necessary. Within the framework of specialized education, it is necessary to incorporate experts and leaders who are working to further information competencies, although they are not recognized by this name, so that the discipline can grow both in size and in visibility.

From the point of view of progress in information literacy in different countries, two different movements can be observed. On the one hand there is the centre-periphery expansion: the more developed countries have clearer and more advanced policies and strategies, and at the same time the organizations belonging to the capital of the nation are more advanced than regional and provincial ones. In this type of movement, the existence of national institutions responsible for the coordination of education and libraries that fully accept information literacy favours the rapid spread of innovations from the centre out to the periphery. Yet there is also another complementary movement based on pioneering projects and very advanced initiatives in countries and institutions that are not in such a central position. The promoters and managers of information literacy would do well to foster both tendencies, thereby ensuring a balance between the two. 
One important contribution made by the study has been the attempt to classify the degree of development of information literacy policies over a continuum, which also offers several important lessons. The initial phase is that of awareness-raising, which must be later backed up by ongoing marketing activities. The next stage is that of diagnosis and planning. Thirdly, it is necessary to train trainers and begin to integrate, by homologating but also by distinguishing, the existing and the new activities, usually based on new pilot projects or on re-engineering existing subjects and training courses for users. This phase must progressively expand both horizontally to other degree courses and macro-areas and vertically toward higher educational levels, and even to training for teachers and researchers. In the next step, it is wise to ensure at least that the training programmes are accredited within the educational curricula. Finally, the only way to make sure that information literacy has really been included in students' training is for it to be a compulsory part of the contents of the curriculum in the form of new subjects, redesigned subjects, or modules with a clearly defined number of credits within the curriculum.

Lastly, as can be observed from the analysis and synthesis of the opinions of our experts, the field of Information Literacy is made up, on the one hand, of a string of classical elements from the training of users and education for research and, on the other, new elements such as digital literacy or training in the new information and communication technologies, together with, more generally, the development of generic competencies. This means having to involve teachers and professionals from different areas, without neglecting any important contribution, tradition or tendency, and incorporating them in an efficient way.

\section{Acknowledgements}

We gratefully acknowledge the participation of the experts consulted in the study and their invaluable contribution:

Paola Ascensión. Librarian. Pontificia Universidad Católica (Peru)

Carlos A. Ávila Araujo. Assistant Professor. Universidade Federal de Minas Gerais - UFMG (Brazil)

Regina Baptista Belluzzo. Lecturer. UNESP - Marília (Brazil)

Aida Bedón. Assessor. Escuela Politécnica del Ejército (Ecuador)

Andoni Calderón. Librarian. Biblioteca de la Universidad Complutense de Madrid (Spain)

Ma. Gladys Ceretta. Lecturer. Escuela Universitaria de Bibliotecología y Ciencias Afines, Universidad de la República (Uruguay)

José de J. Cortés. Senior Lecturer. Universidad Autónonoma de Ciudad Juárez (Mexico)

Ana A. Chiesa. Librarian. Instituto Pío XII (Argentina)

Mercedes Fernández. Lecturer. Centro Nacional de Información de Ciencias Médicas/Infomed (Cuba)

Francisco J. García Marco. Professor. Universidad de Zaragoza (Spain)
Sandra García Rivadulla. Research Librarian. Towers Watson / Universidad de la República (Uruguay)

Álvaro Gascue Quiñones. Lecturer. Universidad de la República (Uruguay)

José A. Gómez. Professor. Universidad de Murcia (Spain)

Ma. del Carmen Ladrón de Guevara. Senior Lecturer.

Universidad Nacional de Córdoba (Argentina)

Jesús Lau. Senior Lecturer. Universidad Veracruzana (Mexico)

Judith Licea. Senior Lecturer. Universidad Nacional Autónoma de México (Mexico)

Gloria Marciales. Senior Lecturer. Pontificia Universidad Javeriana (Colombia)

Berenice Mears. Lecturer. Universidad Autónoma de Ciudad Juárez (Mexico)

Grizly Meneses. Assistant Professor. Departamento Ciencias de la Información, Universidad Central (Cuba)

Alice Miranda. Lecturer. Universidad de Costa Rica (Costa Rica)

Eva Ortoll. Senior Lecturer. Universitat Oberta de Catalunya (Spain)

Cristóbal Pasadas. Research Librarian. Universidad de Granada (Spain)

Analia Povolo. Lecturer. Universidad Nacional de Cuyo (Argentina)

Nelva Quevedo. Research Librarian. Universidad de Lima (Peru) Ada Rengifo. Research Librarian. Pontificia Universidad Católica del Perú (Peru)

Ana María Reusch. Lecturer. Universidad de Playa Ancha, Valparaíso (Chile)

Liuris Rodríguez. Lecturer. Universidad de las Ciencias Informáticas (Cuba)

Lourdes Rovalo. Librarian. Universidad Nacional Autónoma de México (Mexico)

Dora Sales. Senior Lecturer. Universidad Jaume I, Castellón (Spain)

Gerardo Sánchez. Librarian. Universidad Nacional Autónoma de México (Mexico)

Marlery Sánchez. Lecturer. Centro Nacional de Biopreparados (Cuba)

Juan Carlos Sierra. Lecturer. Universidad de La Salle Bogotá (Colombia)

Blanca Estela Solís Valdespino. Lecturer. Universidad Nacional Autónoma de México (Mexico)

Marines Santana Justo Smith. Lecturer. UNESP - Marília (Brazil)

Lourdes Tiscareño. Lecturer. Universidad Autónoma de Ciudad Juárez (Mexico)

Alejandro Uribe. Lecturer. Universidad de Antioquia (Colombia)

Ma. Segunda Varela. Lecturer. Universidad Nacional de Mar del Plata (Argentina)

Aurora de la Vega. Research Librarian. Pontificia Universidad Católica del Perú (Peru) Marcela Verde. Assistant Professor. Universidad Nacional de Córdoba (Argentina)

\section{Declaration of Conflicting Interests}

The author(s) declared no potential conflicts of interest with respect to the research, authorship, and/or publication of this article. 


\section{Funding}

The author(s) disclosed receipt of the following financial support for the research, authorship, and/or publication of this article: Our gratitude also goes to the Ministerio de Ciencia e Innovación (Spain) for funding granted for this work within the framework of the competitive project Investigación y Desarrollo sobre Competencias Informacionales en la Enseñanza Superior (EDU2011- 29290).

\section{References}

Arnold AM (2004) Developing a national information policy. Considerations for developing countries. International Information \& Library Review 36 (2004): 199-207.

Basili C (2011) A framework for analyzing and comparing information literacy policies in European countries. Library Trends 60 (2, Fall): 395-418.

Basili C (2009) Information literacy policies in europe. In: Basili $\mathrm{C}$ (ed.) The Observatory on Information Literacy Polices and Research in Europe. Rome: Consiglio Nazionale delle Ricerche, pp. v-xii.

Brown M (1997) The field of Information Policy. 1: Fundamental concepts. Journal of Information Science 23(4): 261-75.

Caridad Sebastián M (2011) Evaluación y gestión de políticas de información y documentación audiovisual. In: Caridad Sebastián M, et al. (eds) Documentación audiovisual: Nuevas tendencias en el entorno digital. Madrid: Síntesis, pp. 199-226.

Caridad Sebastián M (2006) Políticas de información para Educación: Ámbito europeo. In: Marzal García-Quismondo MA and Andreu Lorenzo LB (eds) La biblioteca: Un mundo de recursos para el aprendizaje. Madrid: Ministerio de Educación y Ciencia, pp. 83-114.

Caridad Sebastián M (coord.) (1999) La sociedad de la información: Política, tecnología e industria de los contenidos. Madrid: Fundación Ramón Areces.

Catts R and Lau J (2008) Towards Information Literacy Indicators. Paris: UNESCO. Available at: http://unesdoc. unesco.org/images/0015/001587/158723e.pdf (accessed 11 January 2011).

Ceretta MG and Picco P (2013) La necesidad de definir un modelo de alfabetización en información para el Plan Ceibal. TransInformação 25(2): 127-133.

Cornellà A (1997) Politicas de información en España. Barcelona: ESADE.

Crawford J and Irving C (2013) Information Literacy and Lifelong Learning. Policy Issues, the Workplace, Health and Public Libraries. Oxford: Chandos.

Hernon P and Relyea HC (2003) Information policy. In: Kent A (ed.) Encyclopedia of Library and Information Science. New York: Dekker, pp. 1300-1315.

Instituto Nacional de Prospectiva (1980) Seminario sobre la Política de Información y Documentación en España. Madrid: Instituto Nacional de Prospectiva.

Jann W and Wegrich K (2007) Theories of the policy cycle. In: Fischer F, et al. (eds) Handbook of Public Policy Analysis: Theory, Politics and Methods, Boca Raton: CRC Press, pp. 43-62.

Karpati A (2011) Digital Literacy in Education. Moscow: UNESCO. Available at: http://iite.unesco.org/pics/publications/en/files/3214688.pdf (accessed 17 December 2016).
Kingdon JW (2003) Agendas, Alternatives, and Public Policies. 2nd edn. New York: Addison-Wesley.

Martínez R and Scott T (2001) Reflexiones sobre políticas nacionales de Información Científica y Tecnológica en Venezuela. Ciencias de la Información 32(1): 9-15.

McClure C and Jaeger PT (2008) Government information policy research: Importance, approaches, and realities. Library \& Information Science Research 30: 257-264.

Montviloff V (1990) Politicas Nacionales de Información. UNESCO, PGI 90/WS/11. Available at: http://unesdoc. unesco.org/images/0008/000869/086995sb.pdf (accessed 27 November 2017).

Moore N (1997) The information policy agenda in East Asia. Journal of Information Science 23(2): 139-47.

Moore N (1998) Policies for an information society. Aslib Proceedings 50(1): 20-24.

Moore N and Steel J (1991) Information-Intensive Britain. British Library $R$ \& D Report No. 6038. London: Policy Studies Institute/British Library Board.

Morales García AM and Caridad Sebastián M (2009) Las políticas de información comunitarias como factor de desarrollo de la Sociedad de la Información: Una mirada crítica sobre su influencia en España. In: Cebrián Herreros M (ed.) Sociedad de la información y del conocimiento en los países nórdicos: Semejanzas y divergencias con el caso español. Barcelona: Gedisa, pp. 337-366.

Oppenheim C (1994) Are national information plans useful? Alexandria 6(2): 133-43.

Orna E (2008) Information policies: Yesterday, today, tomorrow. Journal of Information Science 34(4): 547-565.

Ponjuán G (1993) Las políticas nacionales de información en el contexto latinoamericano. El caso de Cuba. Revista General de Información y Documentación 3(1): 115-122.

Ponjuán G (2010) Guiding principles for the preparation of a national information literacy program. International Information \& Library Review 42: 91-97.

Ponjuán G, Pinto M and Uribe A (2015) Conceptualización y perspectivas de la Alfabetización informacional en Iberoamérica: Un estudio Delphi. Information Research 20(3). Available at: http://www.informationr.net/ir/20-3/ paper680.html (accessed 23 November 2016).

Quindemil E (2008) Políticas de información y su incidencia en la alfabetización informacional. Consideraciones desde la perspectiva cubana. Bibliotecas. Anales de Investigación 4(4): 28-35.

Relyea HC and Hernon P (1968) Information policy. In: Kent A (ed.) Encyclopedia of Library and Information Science, Vol. 48, Supl.11. New York: Marcel Dekker, pp. 176-204.

Rescher N (1998) Predicting the Future: An Introduction to the Theory of Forecasting. Albany: State University of New York Press.

Ros García J (2010) Politicas de información y documentación. Madrid: Síntesis.

Rowlands I (1998) Some compass bearings for information policy orienteering. Aslib Proceedings 50(8): 230-37.

Rowlands I (ed.) (1997) Understanding Information Policy: Proceedings of a British Library Workshop, July 1996. London: Bowker-Saur.

UNESCO IFLA (2003) The Prague Declaration - Towards an Information Literate Society. Prague, Czech Republic, 20-23 
September 2003. Available at: http://portal.unesco.org/ci/en/ ev.php-URL_ID=19636\&URL_DO=DO_TOPIC\&URL_ SECTION=201.html (accessed 7 March 2017).

UNESCO/IFLA (2005) Beacons of the Information Society: The Alexandria Proclamation on Information Literacy and Lifelong Learning, High Level Colloquium on Information Literacy and Lifelong Learning. Available at: http://www. ifla.org/publications/beacons-of-the-information-society-the-alexandria-proclamation-on-information-literacy (accessed 15 November 2016).

Uribe A (2010) Alfabetización informacional: ALFIN Iberoamérica: bibliotecas y proyectos, last modified 2010: http://g.co/maps/x8exn.

Uribe A and Pinto M (2014) 75 lecciones aprendidas en programas de alfabetización informacional en universidades iberoamericanas. Revista Española de Documentación Cientifica 37(3): 1-18.

Weiner SA, Jackman LW and Prause E (2013) Strategizing for Public Policy: The Information Literacy State Proclamation Project. Public Services Quarterly 9(4): 284-299.

Zahariadis N (1999) Ambiguity, time, and multiple streams. In: Sabatier PA (ed.) Theories of the Policy Process. Boulder, CO: Westview Press, pp. 73-96.

Zurkowski PG (1974) The Information Service Environment Relationships and Priorities. Washington, DC: National Commission on Libraries and Information Science. Related Paper No. 5.

\section{Author biographies}

María Pinto has a PhD in History and is Professor of Information Science at the University of Granada, Spain. She is an expert in the field of abstracting, knowledge representation and information literacy.

Francisco-Javier García-Marco has a PhD in Philosophy and Arts and is Professor of Information and Library Science at the University of Zaragoza, Spain. He has researched and published extensively on the theory of information, knowledge organization, digital change and its social, ethical and juridical impact.

Gloria Ponjuán has a PhD in Information Sciences. She is lecturer and researcher at the Communication Faculty, University of La Habana. Cuba.

Dora Sales has a $\mathrm{PhD}$ in Translation Studies. She is Senior Lecturer in Documentation at the University Jaume I of Castellón, Spain. Her research in the field deals with documentation applied to Translation Studies and information literacy.

\section{Appendix}

\section{Discussion form of the third round of the international digital survey study referring to information literacy policies and planning}

Information literacy policies and planning. We know that in the international context, especially in the United States and Australia, information competencies and therefore the aims of Information Literacy have become part of the core of the national educational policy. Accordingly, they have been integrated within the curricular plans, and Information Literacy has become an aim of educational policy that must impregnate society at all levels.

In this same line, UNESCO has asked governments to lend their support to the recognition of INFOLIT as a key element for the development of generic competencies that must be a requirement for accrediting all educational and training programmes. At the same time it is necessary to further the professional development of staff working in the education, library and information sectors in the principles and practices of INFOLIT, as well as in lifelong learning.

Question 1.1 Please state your view of the INFOLIT policies in your country, and more particularly in your Institution.

Planning Information Literacy involves defining actions that help raise the community's awareness about its many benefits, which, as stated by the OECD, allows people to make the change from being dependent on knowledge intermediaries to become creators of knowledge.

INFOLIT must be incorporated within the Institution's Strategic Plan, whether it is a university, school or library, so that a suitable Action Plan can be drawn up. Such a plan must take into account the current and future priorities and needs of different stakeholders, establish strategies that are appropriate for reaching the initially foreseen mission and vision, and make it possible to record, review, appraise, improve and communicate that plan, according to the evidence that is detected.

Question 1.2 Please find out whether INFOLIT is part of the Strategic Plan of your Institution (centre, faculty, library, enterprise, etc.). If your answer is affirmative, please state the actions that are due to be performed. If your answer is negative, please think about any recommendations you would make to improve this situation.

Planning an INFOLIT programme establishes the means required to be able to carry it out and adapt it, and this is linked to the life cycles of the institution where it is implemented, referring more especially to human, technological and financial resources. That planning must give rise to a programme, which makes a contribution to the learning of the information competencies that users have to acquire at both the disciplinary and course levels, as well as to the achievement of results.

Question 1.3 Please state the programmes concerning INFOLIT that your institution has implemented in the last two years.

Please state whether those programmes are part of the Study programme of some degree course or whether they are training activities organized by the library or another service.

If there are no official programmes, please comment on any INFOLIT-related training activities you have undertaken at your centre. 